\title{
The Analysis of the Religious Risk and Countermeasures along the Belt and Road-Taking Thailand as an Example
}

\author{
Meiwu Liu* \\ International Business School \\ Yunnan University of Finance and Economics \\ Kunming, China \\ lmwkm11@sina.com
}

\author{
Wei Zhang \\ International Business School \\ Yunnan University of Finance and economics \\ Kunming China \\ 2437980429@qq.com
}

\begin{abstract}
As an important node country in "Belt and Road" initiative, Thailand has maintained cooperation with China in various aspects, including economy and trade. In addition, compliance with the initiative will undoubtedly provide a broader cooperation opportunity for both two countries. However, the religious factors along the "Belt and Road" have a great influence on politics, economy and other fields. As a religiously prevalent country, Thailand is no exception. The Thai government intends to assimilate Muslims with the culture and values of Buddhism to maintain the status of Buddhism. The compulsory nature of this policy has led to constant conflict between the two religions and even triggered a crisis of terrorism. If the Thai government does not take measures, it will create uncertainties of many aspects, even affecting the implementation of China-Thailand cooperation and the development of the initiative. Therefore, the author proposes to reduce the sectarian conflicts and promote the stability of the domestic situation through the exchanges between Yunnan Muslims and Malay Muslims, the transformation of Thailand's policy of national integration, and religious infiltration, which will all benefit the implement of "Belt and Road" initiative.
\end{abstract}

Keywords_Belt and Road; religious; risk religious penetration

\section{INTRODUCTION}

Thailand is an extremely important business hub in "Belt and Road ". China and Thailand have broad prospects for cooperation and exchanges in various fields. By the end of 2015, China has become Thai largest trading partner. According to the data from the Counsellor's office in Thailand, in 2017, Thai GDP increased by $3.8 \%$ from the same period last year, and the trade volume between China and Thailand increased by 2.5 times [1]. In recent years, there have been a large number of Chinese tourists traveling to Thailand. According to 2016 data from the Ministry of Tourism and Sports of Thailand, it has reached 8.77 million. To sum up, in order to achieve better cooperation and form a win-win situation between two countries, China should adopt an active and effective approach to handling Sino-Thai relations.

Liang Yongjia pointed out that most countries along "Belt and Road" have a long history of religion and strong beliefs, so the religious issues are more complicated even become the core of politics. Only by recognizing, respecting and accepting local religions can ensure the smooth progress of the "Belt and Road" [2].

In Thailand, Buddhism has extensive intersections with public life. As Buddhism becoming a political tool to assimilate other religions, it will be evolved into a religious confrontation, even leading to ethnic opposition in religious forms. Religious risks induced by this including religious disputes and terrorism will all seriously affect the stability of politics and economy in Thailand, even conducive to Sino-Thai cooperation.

This paper proposes to take the religious communication and infiltration as the key point, combining the history and methods of the spread of Christianity in China to maintain the stability in Thailand and promote the implementation of "Belt and Road".

\section{STATUS AND RELATIONS OF RELIGION DiSTRIBUTION IN THAILAND}

Religion in Thailand involves all aspects of people's lives [3]. $95 \%$ of the Thai people believe in Buddhism, $3.8 \%$ believe in Islam and $1.2 \%$ believe in other religions [4].

Since religious risks in Thailand mainly involve Buddhism and Islam, thus, this article focuses on the analysis of these two sects.

In Thailand, Buddhism is the national religion and has significant influence in all areas. For example, Thai constitution stipulates that the king and prime ministers must be Buddhists, and many official and private ceremonies are also required Buddhist etiquette.

Muslims is far less than Buddhists though Islam ranks second in religious beliefs of Thailand. Muslims is main in the northern Thailand and five prefectures in south. There are six Muslim ethnics including Yunnan ethnicity, Burmese ethnicity, Indo-Pakistan ethnicity, Bangladeshi ethnicity, Malay ethnicity, and Thai ethnicity in northern Thailand with a population of about 20,000; the southern five prefectures, in Pattani, Taogong, Yela and Satun, the number of Muslims is more than $70 \%$ of the total population.

*Corresponding author 
The politicization of Buddhism in Thailand is evident. The government tried to assimilate other religious into Buddhism to facilitate its political power. However, religion is often associated with specific ethnic and represent mutual recognition among politics and culture. On the one hand, religion has strengthened national cohesion; on the other hand, religion has a strong exclusivity for external groups. In law, Thailand does not recognize the differences between minority and nationals, emphasizes national integration. But the "assimilation" policy adopted by Thai does not respect the culture of Muslim. Since that Muslims face both of the challenge of Buddhist and poor material conditions for living, Muslims, especially Malay Muslims are dissatisfied. Finally resulting in breaking the balance of religion and evolved into a religious confrontation which ultimately led to ethnic opposition and the tendency of ethnic separation.

From a view of practical political, once the religious beliefs of minority are discriminated against or threatened, the government often faces the threat of the international community. It can be seen that Buddhism is used as a political tool to assimilate Islam, causing many problems, such as political instability and terrorist threats.

\section{RELIGIOUS RISKS}

\section{A. Religious Disputes}

In the northern Thailand, other ethnic Muslims entered later [5], and they lived near the mosques of Yunnan Muslims with the strongest economic and social strength when they entered the northern Thailand. Therefore, other ethnic Muslims have maintained an extremely friendly relationship with Yunnan Muslims, and they are often forced by external Buddhism and the pressure of Thai mainstream culture. They can often abandon internal or geographical differences and jointly handle public affairs within religions [6]. Therefore, in northern Thailand, due to the internal coordination mechanism of Muslims, sectarian conflict is not obvious; but in the five southern prefectures, Muslims are mostly Malay Muslims. The local government's assimilation policy does not respect the difference between different ethnics; economically, the lack of measures to develop and subside the local Malay Muslims have led to their hardships which has intensified the conflicts between the sectarians. Also will it led to the strong dissatisfaction with the Buddhists, the Thai people, and even the local government. Even led to Nationalism and Separation movement [7].

\section{B. Terrorism}

The fundamental reason for the frequent occurrence of riots in the southern Thailand is the Malay Muslims' dissatisfaction with the Thai government, mainly due to poverty, lack of political participation and low ethnic identity [8]. These areas inhabited by Muslims have not been valued by the government, although the rich natural resources of the region are suitable for the development of agriculture, animal husbandry, and planting. And due to the lack of government support, coupled with weak economic foundation and frequent natural disasters, the economy is difficult to be developed, and local life is very poor Under the "assimilation" policy of the Thai government, national inequality has become increasingly prominent, aggravating the pace of the "Separation Movement" in southern Thailand and seriously threatening the stability of Thailand. In addition, because of their low level of education, Malay Muslims have also played a dangerous role in the terrorists, causing prejudice in the Thai mainstream society, followed by discrimination in life and work, which finally increasing their dissatisfaction [9].

At the end of the last century, the impact of Christianity and the colonial rule of Western countries accelerated the division of the Islamic world and gave birth to ideas such as Islamic nationalism, pan-Islamism, and Islamic fundamentalism. The activities of Middle East and international terrorists have a profound impact on Muslims in Southeast Asia [10]. It is the combination of Islam and nationalism. The threat of terrorism in southern Thailand is even more pronounced [11].

\section{Dominated by Powerful Country}

With the expansion of Chinese socialist system in the world causing taboos and fears in western countries led by Europe and the United States. They believe that the development of China has seriously threatened Western ideology and values. Then fabricating a "theory of China threat" to induce the dissatisfaction and resistance of neighboring countries to curb the development of China through unfriendly foreign policy [12].

The Sino-Thai relations are vulnerable to interference by major powers. After the end of the Cold War, the US ignored the allies with Thailand. Since the beginning of Obama's term, the US has proposed returning to the Asia-Pacific and "AsiaPacific rebalancing". Since than beginning to pay attention to the relationship with Thailand, and the bilateral relations rapidly rebounded. After Obama's reelection in 2012, he continued to implement the strategy of "Asia-Pacific rebalancing" and the first stop was Thailand, which shows Thailand's position in its layout. In order to contain China's development, the follow-up also adopted measures to restraint to the exchange and cooperation between China and Thailand. India is warming the relation with ASEAN countries to echo "New Silk Road Plan" of the United States and limit the rising of Chinese position in the Asia-Pacific region. In order to strive for the supremacy of Southeast Asia, Japan is also striving for cooperation with Thailand. When China and Thailand negotiated on railway cooperation in 2015, Japan competed with China for the construction in six rounds. Though China has won the opportunity, the threat of Japan is still cannot be ignored.

\section{RELIGIOUS RISK HAZARDS IN THAILAND}

\section{A. Political Instability in Thailand and Its Surroundings}

The Thai government regarded Buddhism as "state religion" and tried to "assimilate" Islamic culture, resulting in opposition between the two religions and causing religious disputes. Economically, it has not adopted national treatment and ignored their advantages of resources, causing the local economy lag behind and people's poor livel. Culturally, it highlights the superiority of local culture and discriminates against Islamic culture. These various reasons such as religion, economy, and culture will intensify the national separatist 
movement and terrorism in Thailand, thus threatening domestic security in all aspects.

In addition, the religious risk in Thailand will not only affect its domestic political environment, but also radiate and spillover in neighboring countries. Southeast Asian countries are places where religion is prevalent. Terrorism and national separatist movements also occur from time to time. As an important Southeast Asian country, Thailand's internal threat spillovers will exacerbate political crisis and security threats in the region.

\section{B. Security Crisis Triggered by Terrorist Threat}

The threat of terrorism is not only reflected in the political stability of the country and its surrounding areas, but also seriously threatens the personal safety of the area where the activity takes place. With the booming tourism industry in Thailand, the surrounding countries, especially China, the number of tourists visiting Thailand increasing quickly. In addition, with the deepening of Sino-Thai cultural exchanges, the number of Chinese expatriates living in Thailand and various industries visiting Thailand has also increased. In the event of a terrorist attack, the victims will be far more than local residents. The personal safety of a large number of tourists, including nationals and overseas Chinese will be threatened.

\section{Economic Risk}

Under the returning trend of globalization, the infiltration between terrorism and anti-globalization organizations has been intensified. With the terrorist attacks in Thailand, antiglobalization is inevitably appear. Therefore, a series of Chinese infrastructure construction and economic activities in Thailand may become its objection, which will cause great uncertainty to enterprises, personnel and property. All of these has seriously affected the enthusiasm of Chinese entrepreneurs to visit Thailand for business. In addition, Thai nationals mostly have higher religious beliefs. As Yan Xuetong wrote in the "Analysis of International Relations": The highest interest in most countries is not necessarily material economic development, on the contrary, may be the pursuit of spiritual values or religious beliefs. This kind of knowledge can help us understand why China's foreign policy which aims to serve economic construction has not effectively eliminated the theory of " China threat ". If China do not adopt the infiltration and dissemination of values, such as religious infiltration, it may be difficult to obtain expected benefits, even more civil interference.

Thailand's social organizations are powerful. They will pose a threat to the safety of facilities and properties once they are opposed. The failure of the Myitsone Hydropower Project is a typical example. Therefore, we should advocate the transfer of both material and spiritual values and use both hardware and software to provide more guarantees for strategies.

\section{COUNTERMEASURES AND SUGGESTIONS}

\section{A. Adjust the National Integration Policy}

Thai government adopted a tough national assimilation policy when integrated Malay Muslims. Not only did it inhibit ethnic diversity and give little respect to Malay Muslims, but also did it attempted to assimilate its ideas with Buddhist culture and values. It did not implement freedom of religious belief and the result was counterproductive. Thus, Thai government should change its national integration policy into a new one based on the integration of ethnic cultures. Its characteristics of complementing each other can create a richer economy and culture without losing Islam cultural characteristics. Adopting the national integration policy not only benefits the unity of all ethnic groups, maintains domestic order, but also promotes cultural, economic, political and other aspects of development.

\section{B. Intra-religious Communication}

Malay Muslims were originally close to the most powerful Yunnan Muslims in economic and social power when they were exiled to Thailand. Therefore, they gratitude and respect the Yunnan Muslims. According to this, it is possible to draw or improve Malay Muslim perceptions of the Chinese government, then reduce conflict and promote smooth cooperation between China and Thailand.

\section{Sino-Thai Cooperation of Religion Infiltration and Economic Support}

With religious infiltration as the mainstay and economic support as a supplementary way to communicate with Malay Muslims, Thai government, Malay Muslims and China will be all benefited. First of all, Thai policy of ethnic assimilation has been resisted by its mandatory nature, and the effect is counterproductive. While the adoption of both religious infiltration and economic support can help them achieve goals to stabilize Buddhism's status and promote stability in culture, economy, and politics. As for Malay Muslims, they can receive assistance and respect from Chinese and local governments. Not only does it improve the material living conditions, but also can be comforted on the spiritual level, thereby ease its hostile attitude towards the government and Buddhism. Combining the history of Christianity in China and theory of religious markets, when people have or become stronger attachments with people of different traditional religions, they will change their belief. The choice of believers in religious life is rational and it is expected that they can exchange their best interests at the lowest price. Therefore, it is possible to infiltrate and guide Malay Muslims to Buddhism. Finally, the stability and security of Thailand can promote Sino-Thai cooperation and implementation of the "Belt and Road ".

The origins and developments of religion have a large extent exploited the needs of believers for the material and spiritual world. Religious penetration refers specifically to infiltrating in the name or form of religion, ultimately affecting or dominating the region's social culture and ideology. And in the current context of utilitarian beliefs, utilitarianism has become the most tangible starting point for discussing changes in religious beliefs. This can be used as a reference for Christianity's methods of dissemination in China, according to 
the characteristics of poor local life and education, cooperation with the Thai government in the name of a Buddhist organization or private enterprise to invest in setting up schools, instilling Chinese and Buddhist values in a subtle manner in education; setting up public services such as welfare and fundraising; using Buddhist temples to compose Buddhist scriptures to enrich the people's poor spiritual life, etc. In order to promote the relationship between the two religions, reduce sectarian conflicts, and jointly maintain the stability of the country's economy and politics, it is of great help to establish a good image for China and promote exchanges and cooperation between the two countries.

\section{CONCLUSION}

In summary, if the implementation of the "assimilation" policy of ethnic assassination through the exchange of religious infiltration and the same-sectarians, it may not only achieve Thailand's goal of fully implementing Buddhism, stabilizing all aspects of the domestic situation, reducing conflicts and eliminating the threat of terrorism; dealing with problems between Thai government and Malay Muslims can also improve the diplomatic relations between China and Malaysia to maintain the peace and stability of the Indochina Peninsula; It is also closely related to safety and happiness.

In addition, the method of infiltrating the soft power of religion as an example is not easily affected by the local government and social forces. At the same time of promoting exchanges, not only will it win the goodwill of the Thai people, but also reduces the uncertainty in all aspects. It can get support from the Thai government to facilitate further exchanges between China and Thailand in economic, political and cultural aspects.

In the end, while safeguarding the peace and stability of Thailand and even the Indochina Peninsula, it has won the respect and support of all countries, promoted the overall international status, demonstrated China's standing as a big country in the East and made the Western countries' attempts to isolate China from being defeated. This will promote the implementation of the "Belt and Road" and AIIB and many other China-sponsored strategic initiatives.

\section{ACKNOWLEDGMENT}

This research paper was partially supported by International Business School, Yunnan University of Finance and Economics. We thank our colleagues from International Business School who provided insight and expertise that greatly assisted the research, although they may not agree with all of the interpretations of this paper. Also as phased achievement, it is sponsored by Research Office of Yunnan University of Finance and economics and International Business School.

We would also like to show our gratitude to the moderators for sharing their pearls of wisdom with us during the course of this research. And we also immensely grateful to reviewers for their comments on an earlier version of the manuscript. In addition, we would also thank peer reviewer for comments that greatly improved the manuscript.

Last, but not least, We recognize that this research would not have been possible without the financial assistance of the University of Finance and Economics, and other institutions, and express my gratitude to those agencies.

\section{REFERENCES}

[1] Counsellor's office in Thailand

[2] Liang Yongjia, Li Xiaoyun. The implementation of the "One Belt and One Road" strategy requires religious considerations [EB/OL]. http://news.ifeng.com/a/20150430/43669863-0.shtml,2015.

[3] Chinese Ethnic Religion Network: Overview of Thai Ethnic Religions http://www.mzb.com.cn/html/Home/report/316402-1.html

[4] Yuan Zhenjun. Law and religion in Thailand [D]. Guangxi University, 2015 .

[5] Wa Xi Han Rui, Mr. He Guodao Interpreter: "A Brief History of Muslims and Muslims."

[6] Yao Jide. Society and Culture of Yunnan Muslims in Northern Thailand [J]. Chinese Hui Studies, 2005, 1(00): 389-436.

[7] Yan Qing, "The Ideas, Patterns and Measures of National Integration", "Research in Political Science", 2015(1), pp.11-20.

[8] Chalita Bundhuwong. Economic Life of Malay Muslims in Southernmost Thailand Amidst Ecological Changes and Unres,t[D] . East Eisenhower Parkway: Pro Quest LLC,2013,pp. 285-286.

[9] The Chinese People's Republic of China Qiao and the State Department of the Lost King's Embassy at the Commercial Office Participation: Counsellor, Department of Business, Thailand: http://th.mofcom.gov.cn/aiticle/jmxw/201412/20141200850963.shtml.

[10] Prayoonchat Maneennat. The study of the problem of Tarantan terrorism separation[D].Yunnan University,2015.

[11] Wang Licheng. Analysis of potential and risk of Sino-Thai cooperation under the "One Belt and One Road" initiative [D]. Central China Normal University, 2016.

[12] Peng Zhen. "China Threat Theory" - Influences and Countermeasures [D]. Xiangtan University, 2010. 